\title{
Pengaruh Perputaran Piutang dan Perputaran Persediaan terhadap Return on Asset pada Perusahaan Otomotif dan Komponen Periode 2013-2018
}

\author{
The effect of receivable turnover and inventory turnonver on return on asset against \\ automotive companies period 2013-2018
}

\section{Evi Fujilestari}

Program Studi D3 Keuangan dan Perbankan, Politeknik Negeri Bandung

E-mail: eviflstr@gmail.com

\section{Radia Purbayati}

Jurusan Akuntansi, Politeknik Negeri Bandung

E-mail: radia.purbayati@polban.ac.id

\section{Fatmi Hadiani}

Jurusan Akuntansi, Politeknik Negeri Bandung

E-mail: fatmi.hadiani@polban.ac.id

\begin{abstract}
The purpose of this research is to test the effect of receivable turnover and inventory turnonver toward Return On Asset (ROA). The research sample are used Automotive Companies Listed on Indonesia Stock. Exchange Period 2013 - 2018, using purposive sampling method are 6 companies. The data are used secondary data from financial statement of companies published by Indonesia Stock. Exchange through the official website of Indonesia Stock Exchange namely www.idx.co.id. Analyse technique are used the multiple linear regression with EV iews of 10 version. The results showed that receivable turnover has no significant effect on $\mathrm{RO} A$ with significance value greater than 0.05, which is 0.8201, inventory turnover is positive and significant with significance value smaller than 0.05 , which is 0.0065 .
\end{abstract}

Keywords: receivable turnover, inventory turnover, and return on asset

\section{Pendahuluan}

Pertumbuhan ekonomi di Indonesia tahun 2019 mencapai 5,02\% turun sekitar 0,15\% dari pertumbuhan ekonomi pada tahun sebelumnya yaitu 5,17\% (Badan Pusat Statistik 2020). Adanya penurunan pada pertumbuhan ekonomi turut memicu penurunan saham-saham perusahaan yang terdaftar di BEI.

Perusahaan otomotif dan komponennya termasuk ke dalam subsektor aneka industri. Perusahaan Otomotif dan Komponen di Indonesia sampai saat ini sudah ada 13 perusahaan yang terdaftar di BEI. Maka dari itu perusahaan otomotif dan komponennya merupakan suatu prospek usaha yang menjanjikan.

Industri otomotif merupakan salah satu sektor manufaktur yang mendapatkan prioritas pengembangan pada saat ini. Sejak 2012, nilai ekspor produk otomotif di Indonesia lebih tinggi daripada impornya. Hingga Juli 2019, nilai ekspor produk otomotif telah melampaui 50\% dari pencapaian ekspor tahun sebelumnya. Perkembangan industri otomotif juga akan dipacu melalui 
peningkatan kapasitas seiring dengan masuknya sejumlah investasi (kemenperin.go.id).

Dengan masuknya sejumlah investasi menyebabkan bertambahnya modal kerja dan akan berpengaruh pada kelangsungan kinerja perusahaan dalam jangka panjang, karena perusahaan akan memperluas penjualan dan meningkatkan produksinya. Kemungkinan besar perusahaan akan mengalami peningkatan keuntungan (profitabilitas).

Berikut merupakan perkembangan kondisi perputaran piutang, persediaan dan ROA pada perusahaan sub sektor otomotif dan komponennya periode 2013-2018:

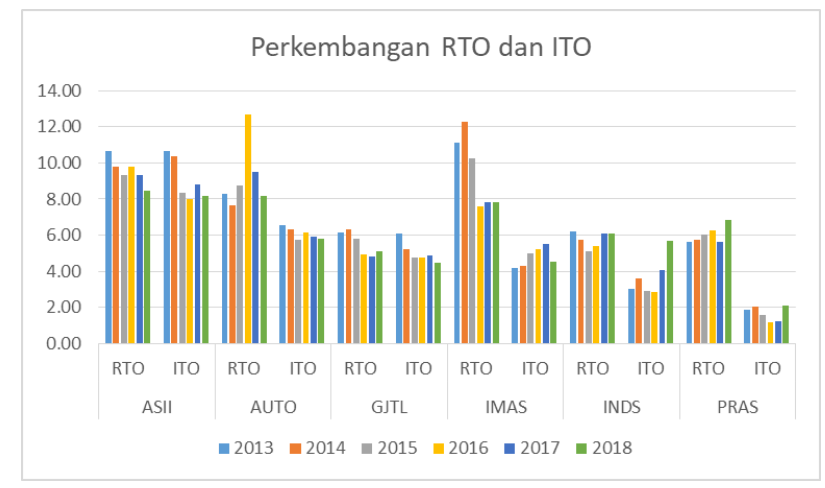

Sumber: www.idx.co.id (diolah kembali)

Gambar 1.1 Perkembangan Perputaran Piutang dan Perputaran Persediaan

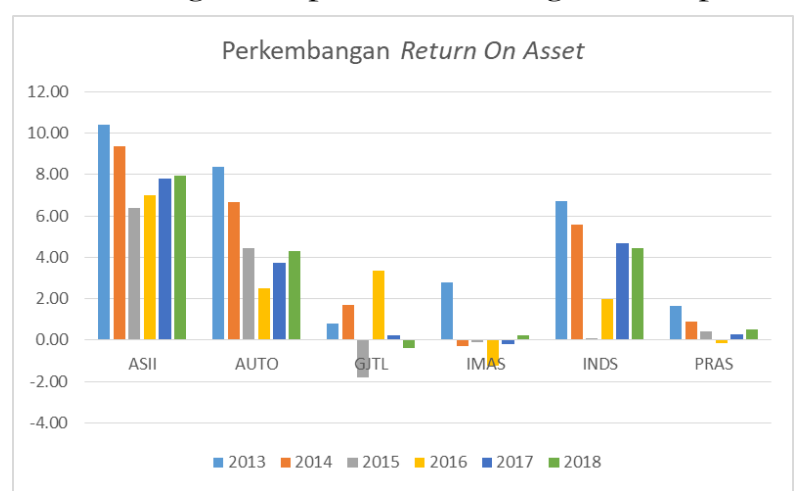

Sumber: wmw.idx.co.id (diolah kembali)

Gambar 1.2 Perkembangan ROA

Berdasarkan gambar di atas terlihat masing-masing perputaran piutang, perputaran persediaan dan ROA perusahaan dari tahun 2013 sampai 2018. Dalam gambar 1.1 data perputaran piutang dan perputaran persediaan fluktuatif setiap tahun. Tahun 2014 perputaran piutang dan perputaran persediaan pada PT PRAS cenderung naik, namun perkembangan ROA-nya menurun. Tahun 2016 perputaran piutang dan perputaran persediaan pada PT AUTO cenderung naik, namun perkembangan ROA-nya mengalami penurunan. Tahun 2017 perputaran piutang dan perputaran persediaan pada PT AUTO cenderung turun, namun perkembangan ROA mengalami kenaikan dan perputaran piutang dan perputaran persediaan pada PT IMAS cenderung naik, namun ROA-nya mengalami penurunan. Tahun 2018 perputaran piutang dan perputaran persediaan pada PT ASII, PT AUTO dan PT IMAS cenderung turun, namun perkembangan ROAnya mengalami kenaikan.

Fenomena tersebut berbanding terbalik dengan teori yang sudah disampaikan oleh peneliti terdahulu yang menyatakan bahwa bila perusahaan memiliki perputaran piutang dan perputaran persediaan yang tinggi, maka perusahaan akan lebih untung karena modal yang disalurkan dalam bentuk piutang dan persediaan akan lebih banyak sehingga menambah laba perusahaan (Muslimah 
dan Syarief, 2020). Piutang dan persediaan harus dikelola dengan baik, karena piutang dan persediaan merupakan unsur sangat penting dalam modal kerja, karena modal kerja merupakan aktiva lancer yang tersedia untuk kegiatan operasional perusahaan. Oleh karena itu, kemampuan manajemen perusahaan dalam mengelola piutang dan persediaan dapat mempengaruhi kestabilan ROA perusahaan sehingga sangat penting melakukan evaluasi akan profitabilitas perusahaan tersebut, terutama dalam hubungannya dengan pihak eksternal.

Pada penelitian terdahulu terdapat perbedaan hasil, (Deni 2014) dengan melihat pengaruh tingkat perputaran kas, perputaran piutang dan perputaran persediaan terhadap profitabilitas, hasil penelitian tersebut menyatakan bahwa perputaran piutang dan perputaran persediaan berpengaruh signifikan terhadap profitabilitas. Penelitian lainnya diteliti oleh (Migang and Irawan 2019) dengan melihat pengaruh cash turnover, working capital turnover, receivable turnover dan inventory turnover terhadap return on asset hasil penelitian tersebut menyatakan bahwa receivable turnover tidak berpengaruh signifikan terhadap ROA dan inventory turnover tidak berpengaruh signifikan terhadap ROA.

\section{Kajian Pustaka}

\subsection{Perputaran Piutang}

Rasio yang dapat mengukur berapa lama penagihan piutang selama 1 periode atau berapa kali dana yang ditanam dalam piutang berputar dalam 1 periode biasa disebut perputaran piutang (Kasmir 2014). Semakin cepat perputaran piutangnya, maka semakin efektif perusahaan dalam mengelola modal kerjanya, sehingga perusahaan tidak terhambat dalam melakukan kegiatan operasionalnya.

\subsection{Perputaran Persediaan}

Persediaan adalah sejumlah barang yang disimpan oleh perusahaan dalam suatu tempat (gudang). Persediaan merupakan cadangan perusahaan untuk proses produksi atau penjualan pada saat dibutuhkan (Kasmir 2014). Perputaran Persediaan merupakan salah satu rasio yang dapat mengendalikan jumlah persediaan. Perputaran persediaan merupakan perbandingan antara jumlah harga pokok barang yang dijual dengan nilai rata-rata persediaan yang dimiliki oleh perusahaan (Munawir 2010).

\subsection{Return On Asset (ROA)}

Rasio untuk mengukur kemampuan suatu aktiva perusahaan dengan seluruh modal kerja yang dimiliki untuk menghasilkan laba operasi perusahaan dan dinyatakan dalam persentase biasa disebut dengan Return on Asset. Return on assets juga sering kali disebut sebagai rentabilitas ekonomi atau earning power (Prakarsa dan Setiawan, 2018).

\section{Metode Penelitian}

Perusahaan-perusahaan subsektor otomotifn dan komponen yang terdaftar di BEI pada periode tahun 2013-2018 yang berjumlah 13 perusahaan merupakan populasi dari penelitian ini. Melalui teknik purposive sampling, dari jumlah populasi sebanyak 13 perusahaan, maka didapatkan sampel dengan jumlah 6 perusahaan. Untuk melakukan analisis data, penelitian ini menggunakan program Eviews 10 untuk pengolahan data. Analisis data yang digunakan untuk penelitian ini adalah regresi data panel.

\section{Pendekatan Model Regresi Data Panel}

Pengujian regresi data panel memiliki tiga pendekatan yang harus diketahui dan dilakukan pengujian untuk menentukan model yang sesuai, diantaranya yaitu Common Effect Model, Fixed Effect Model, dan Random Effect (Widarjono 2018). Berikut ini merupakan pengertian dari tiga pendekatan model regresi data panel: 


\section{Common Effect Model (CEM)}

Common effect model merupakan pendekatan model regresi paling sederhana yang hanya mengkombinasikan antara data time series dan data cross section dalam bentuk pool (data panel) dan cara mengestimasinya melalui pendekatan OLS (Ordinary Least Square) atau kuadrat terkecil (Astuti, 2010).

\section{Fixed Effect Model (FEM)}

Pendekatan fixed effect model mengasumsikan bahwa intersep $(\alpha)$ dan slope $(\beta)$ dari persamaan regresi dianggap stabil baik antar data time series maupun antar data cross section (Zainal, 2007).

3. Random Effect Model (REM)

Pendekatan yang dipakai pada model ini mengasumsikan bahwa setiap unit data cross section (perusahaan) mempunyai perbedaan intersep (variable random atau acak).

\section{Pengujian Model Regresi Data Panel}

Menurut (Basuki and Prawoto 2016), untuk menentukan model yang sesuai untuk mengelola regresi data panel dapat melalui 3 pendekatan, yaitu sebagai berikut:

\section{Uji Chown}

Uji Chow adalah suatu langkah pengujian yang bertujuan untuk memilih antara Common Effect Model (CEM) atau Fixed Effect Model (FEM) yang sesuai digunakan dalam mengestimasi data panel dan pengujiannya menggunakan program Eviews 10.

Melihat nilai probabilitas pada Cross-Section Chi-Square dengan pedoman:

a. Jika nilai probabilitas pada Cross-Section Chi-Square $>0,05$ artinya model yang sesuai adalah Common Effect Model.

b. Jika nilai probabilitas pada Cross-Section Chi-Square $<0,05$ artinya model yang sesuai Fixed Effect Model.

2. Uji Hausman

Uji Hausman adalah langkah pengujian statistic untuk memilih atau menentukan model yang paling tepat antara Fixed Effect Random atau Random Effect Model dalam mengestimasi data panel dan pengujiannya menggunakan program Eviews 10.

Melihat nilai probability (p value) pada Cross-Section Random dengan pedoman:

a. Jika nilai probability pada Cross-Section Random > 0,05 artinya model yang sesuai Random Effect Model.

b. Jika nilai probability pada Cross-Section Random $<0,05$ artinya model yang sesuai Fixed Effect Model.

3. Uji Lagrange Multiplier (LM)

Lagrange Multiplier (LM) Test adalah suatu langkah pengujian statistik untuk membandingkan atau menentukan model yang sesuai antara Random Effect Model atau Common Effect Model dalam mengestimasi data panel dan pengujiannya menggunakan program Eviews 10.

Melihat nilai probability ( $p$ value) pada Cross-Section Random dengan pedoman:

a. Apabila nilai statistik LM > Chi-Square artinya model yang sesuai adalah Common Effect Model.

b. Apabila nilai statistik LM < Chi-Square artinya model yang sesuai adalah Random Effect Model.

\section{Pengujian Hipotesis}

\section{Koefisien Determinasi $\left(\mathbf{R}^{2}\right)$}

Pengukuran koefisien determinasi $\left(\mathrm{R}^{2}\right)$ bertujuan untuk menilai seberapa jauh kemampuan model regresi linier dalam menerangkan variasi variable dependen atau terikat $(\mathrm{Y})$ atau dengan kata lain seberapa besar pengaruh total variabel-variabel independen (bebas) terhadap variable dependen 
(terikat). Koefisien determinasi $\left(\mathrm{R}^{2}\right)$ memiliki nilai antara 0 (nol) sampai satu (1).

\section{Uji Parsial (Uji t)}

Uji t yaitu pengujian hubungan secara parsial (terpisah) yang memiliki tujuan untuk mengetahui signifikansi atau pengaruh variabel independen secara individu terhadap variabel terikat. Data yang digunakan untuk analisis ini umumnya kuantitatif (skala interval atau rasio) dengan asumsi data berdistribusi normal.

\section{Uji Simultan (Uji F)}

Uji $\mathrm{F}$ bertujuan untuk mengetahui seberapa besar pengaruh atau signifikansi variabel independen secara simultan terhadap variable dependen. Pengujian ini juga dikenal dengan nama uji serentak yang digunakan untuk mengetahui apakah model yang dibuat itu baik (siginifikan) atau tidak baik (non signifikan).

\section{Hasil dan Pembahasan}

\subsection{Penentuan Model Regresi Data Panel}

Uji Chow

Berikut merupakan hasil uji chow dengan menggunakan EViews 10.

\begin{tabular}{lrrr} 
Redundant Fixed Effects Tests & & & \\
Equation: Untitled \\
Test cross-section fixed effects \\
\hline \hline Effects Test & Statistic & d.f. & Prob. \\
\hline \hline Cross-section F & 8.465823 & $(5,28)$ & 0.0001 \\
Cross-section Chi-square & 33.155329 & 5 & 0.0000 \\
\hline \hline
\end{tabular}

Gambar 4.1 Hasil Uji Chow

Dari gambar di atas, diperoleh nilai probabilitas $\mathrm{F}$ dan nilai probabilitas chi square lebih kecil dari 0,05, sehingga dapat disimpulkan bahwa pendekatan dengan FEM lebih sesuai daripada pendekatan dengan CEM.

\section{Uji Hausman}

Berikut ini merupakan hasil uji hausman dengan menggunakan EViews 10.

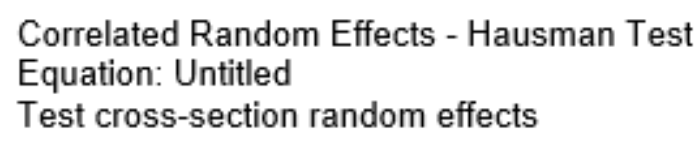

\begin{tabular}{lrrr}
\hline \hline Test Summary & $\begin{array}{r}\text { Chi-Sq. } \\
\text { Statistic }\end{array}$ & Chi-Sq. d.f. & Prob. \\
\hline \hline Cross-section random & 0.125108 & 2 & 0.9394 \\
\hline \hline
\end{tabular}

Gambar 4.2 Hasil Uji Hausman

Dari gambar diatas, diperoleh nilai probabilitas cross-section yaitu sebesar 0,9394. Nilai probabilitas tersebutl ebih besar dari 0,05, sehingga dapat disimpulkan bahwa pendekatan yang lebih sesuai adalah pendekatan dengan REM.

\subsection{Regresi Berganda dengan Random Effect Model}

Berdasarkan hasil penentuan model regresi data panel, maka dapat disimpulkan bahwa REM 
Evi Fujilestari, Radia Purbayati, Fatmi Hadiani

adalah model yang paling sesuai untuk digunakan.

\begin{tabular}{|c|c|c|c|c|}
\hline \multicolumn{5}{|c|}{$\begin{array}{l}\text { Dependent Variable: ROA? } \\
\text { Method: Pooled EGLS (Cross-section random effects) } \\
\text { Date: } 06 / 24 / 20 \text { Time: } 21: 23 \\
\text { Sample: } 20132018 \\
\text { Included observations: } 6 \\
\text { Cross-sections included: } 6 \\
\text { Total pool (balanced) observations: } 36 \\
\text { Swamy and Arora estimator of component variances }\end{array}$} \\
\hline Variable & Coefficient & Std. Error & t-Statistic & Prob. \\
\hline $\begin{array}{c}\text { C } \\
\text { PPIUTANG? } \\
\text { PPERSEDIAAN? } \\
\text { Random Effects } \\
\text { (Cross) } \\
\text { _ASII--C } \\
\text { _AUTO-C } \\
\text { _GJTL--C } \\
\text { _INDS--C } \\
\text { _IMAS--C } \\
\text { _PRAS--C }\end{array}$ & $\begin{array}{r}1.398212 \\
0.974687 \\
-2.344991 \\
-2.343190 \\
1.842351 \\
0.472931\end{array}$ & $\begin{array}{l}2.364629 \\
0.238104 \\
0.314723\end{array}$ & $\begin{array}{r}-0.474059 \\
-0.229191 \\
2.905742\end{array}$ & $\begin{array}{l}0.6386 \\
0.8201 \\
0.0065\end{array}$ \\
\hline \multicolumn{5}{|c|}{ Effects Specification } \\
\hline $\begin{array}{l}\text { Cross-section random } \\
\text { Idiosyncratic random }\end{array}$ & & & $\begin{array}{l}2.474950 \\
1.682705\end{array}$ & $\begin{array}{l}0.6839 \\
0.3161\end{array}$ \\
\hline \multicolumn{5}{|c|}{ Weighted Statistics } \\
\hline $\begin{array}{l}\text { R-squared } \\
\text { Adjusted R-squared } \\
\text { S.E. of regression } \\
\text { F-statistic } \\
\text { Prob(F-statistic) }\end{array}$ & $\begin{array}{l}0.217180 \\
0.169736 \\
1.634205 \\
4.577633 \\
0.017596\end{array}$ & \multicolumn{2}{|c|}{$\begin{array}{l}\text { Mean dependent var } \\
\text { S.D. dependent var } \\
\text { Sum squared resid } \\
\text { Durbin-Watson stat }\end{array}$} & $\begin{array}{l}0.824874 \\
1.793488 \\
88.13066 \\
1.518765\end{array}$ \\
\hline \multicolumn{5}{|c|}{ Unweighted Statistics } \\
\hline $\begin{array}{l}\text { R-squared } \\
\text { Sum squared resid }\end{array}$ & $\begin{array}{l}0.488450 \\
201.3007\end{array}$ & $\begin{array}{l}\text { Mean depen } \\
\text { Durbin-Wats }\end{array}$ & $\begin{array}{l}\text { dent var } \\
\text { on stat }\end{array}$ & $\begin{array}{l}3.084167 \\
0.664925\end{array}$ \\
\hline
\end{tabular}

Gambar 4.3 Regresi dengan REM yaitu:

Berdasarkan output di atas persamaan regresi menggunakan pendekatan Random Effect Model

\section{ROA $=$-1,120974 - 0,054571 Perputaran Piutang + 0,914503 Perputaran Persediaan} berikut :

Diperoleh juga persamaan setiap perusahaan yang menjadi objek penelitian adalah sebagai

1. PT Astra International Tbk

ROA $=1,398212-1,241183$ Perputaran Piutang + 1,397746 Perputaran Persediaan

2. PT Astra Otoparts Tbk

ROA $=$ 0,974687 - 1,241183 Perputaran Piutang + 1,397746 Perputaran Persediaan

3. PT Gajah Tunggal Tbk

ROA $=-2,344991-1,241183$ Perputaran Piutang + 1,397746 Perputaran Persediaan 
4. PT Indomobil Sukses Internasional Tbk

ROA $=-1,842351-1,241183$ Perputaran Piutang + 1,397746 Perputaran Persediaan

5. PT Indospring Tbk

ROA $=-2,343190-1,241183$ Perputaran Piutang + 1,397746 Perputaran Persediaan

6. PT Prima Aloysteel Universal Tbk

ROA $=0,472931-1,241183$ Perputaran Piutang + 1,397746 Perputaran Persediaan

\subsection{Uji Hipotesis}

\section{Koefisien Determinasi}

Nilai $R$ Squared yang diperoleh sebesar $0,217180<0,5$. Hal ini menunjukkan bahwa kemampuan variabel Perputaran Piutang dan Perpiutaran Persediaan tidak kuat dalam menjelaskan variable ROA. Nilai Adjusted R-squared menunjukkan koefisien determinasi yang hasilnya dinyatakan dalam persentase. Nilai koefisien determinasi sebesar 0,169736 atau 16,974\%.

\section{Uji Parsial (Uji t)}

Berdasarkan gambar 4.3, dapat dilihat bahwa:

1. Nilai probabilitas Perputaran Piutang sebesar 0,8201 >0,05, sehingga dapat disimpulkan bahwa variabel Perputaran Piutang secara parsial tidak memiliki pengaruh terhadap ROA.

2. Nilai probabilitas Perputaran Persediaan sebesar $0,0065<0,05$, sehingga dapat disimpulkan bahwa Perputaran Persediaan secara parsial memiliki pengaruh yang signifikan terhadap ROA.

\section{Uji Simultan (Uji F)}

Berdasarkan gambar 4.3, diperoleh Probabilitas F-statistic sebesar 0,017596 < 0,05, sehingga dapat disimpulkan bahwa secara simultan variabel Perputaran Piutang dan Perputaran Persediaan berpengaruh signifikan terhadap ROA.

\subsection{Pembahasan}

\section{Pengaruh Perputaran Piutang terhadap ROA}

Berdasarkan hasil di atas, diperoleh bahwa Perputaran Piutang tidak berpengaruh secara parsial terhadap ROA. Hal ini ditunjukkan oleh nilai probabilitas Perputaran Piutang yang lebih besar dari 0,05 yaitu sebesar 0,8201 . Hal ini menunjukkan bahwa hasil penelitian yang diperoleh tidak sesuai dengan teori dan berarti hipotesis penelitian ini ditolak.

Kondisi tersebut dapat terjadi karena perputaran piutang perusahaan dalam penelitian ini sangat rendah berada dibawah standar industri perputaran piutang, sehingga banyaknya piutang yang tak tertagih dan terjadi over investment pada piutang mengakibatkan tidak berdampak signifikan terhadap profitabilitas perusahaan.

Penelitian ini sesuai dengan penelitian yang dilakukan oleh (Khabilah Umayta, Diana, and Afifudin 2019) yang mengatakan bahwa secara parsial tidak terdapat pengaruh antara perputaran piutang terhadap Return On Asset. Terdapat pula penelitian yang dilakukan oleh (Nurafika 2018) menunjukkan hasil bahwa tidak terdapat pengaruh yang signifikan antara variabel perputaran piutang terhadap Return On Asset.

Hasil penelitian ini tidak sesuai dengan penelitian yang dilakukan oleh (Ananda and Dewi 2019) yang mengatakan bahwa perputaran piutang berpengaruh signifikan terhadap ROA. Hasil penelitian ini juga tidak sesuai dengan penelitian yang dilakukan oleh (García-Teruel and Martínez- 
Solano 2007) yang mengatakan perputaran piutang berpengaruh signifikan terhadap Return On Asset.

\section{Pengaruh Perputaran Persediaan terhadapn ROA}

Berdasarkan hasil di atas, diperoleh bahwa Perputaran Persediaan berpengaruh signifikan secara parsial terhadap ROA. Hal ini ditunjukkan oleh nilai probabilitas Perputaran Persediaan yang lebih kecil dari 0,05 yaitu sebesar 0,0065. Koefisien regresi Perputaran Piutang bernilai positif yaitu sebesar 0,914503. Pengaruh positif ini berarti terdapat pengaruh yang searah antara Perputaran Persediaan dan ROA, sehingga jika terjadi peningkatan Perputaran Persediaan sebesar 1\% akan menyebabkan rasio ROA meningkat sebesar 0,914503\% dengan asumsi variable independen lainnya tetap. Tingkat perputaran persediaan yang tinggi menyebabkan meningkatnya ROA pada perusahaan otomotif dan komponen. Hal ini berarti hipotesis yang menyatakan bahwa Perputaran Persediaan berpengaruh signifikan terhadap ROA diterima. Hal ini menunjukkan bahwa perusahaan-perusahaan otomotif dan komponen dalam penelitian ini telah mengelola persediaan yang dimiliki dengan efektif.

Hasil penelitian ini sesuai dengan penelitian yang dilakukan oleh (Wijaya and Tjun Tjun 2018) yang mengatakan bahwa secara parsial terdapat pengaruh antara Perputaran Persediaan terhadap ROA.

Hasil penelitian ini tidak sesuai dengan penelitian yang dilakukan oleh (Khabilah Umayta, Diana, and Afifudin 2019) yang menyatakan bahwa Perputaran Persediaan tidak berpengaruh secara parsial terhadap Return On Asset. Hasil penelitian ini berbanding terbalik dengan penelitian yang dilakukan oleh (Migang and Irawan 2019) mengatakan bahwa variabel Perputaran Persediaan tidak mempunyai pengaruh signifikan secara parsial terhadap Return On Asset.

\section{Pengaruh Perputaran Piutang dan Perputaran Persediaan Secara Simultan terhadap ROA}

Berdasarkan hasil pengujian di atas, diperoleh nilai probabilitas (F-statistic) lebih kecil dari 0,05 yaitu sebesar 0,017596. Hal ini menunjukkan bahwa Perputaran Piutang dan Perputaran Persediaan memiliki pengaruh secara simultan terhadap ROA. Hasil output menjelaskan bahwa ROA dipengaruhi oleh Perputaran Piutang dan Perputaran Persediaan sebesar 16,974\% dan sisanya dijelaskan oleh variabel lain yang tidak diteliti.

Hasil penelitian ini sesuai dengan penelitian yang dilakukan oleh (Wijaya and Tjun Tjun 2018) yang mengatakan bahwa cash turnover, receivable turnover, dan inventory turnover berpengaruh signifikan secara simultan terhadap $\mathrm{RO} A$.

Hasil penelitian ini tidak sesuai dengan penelitian yang dilakukan oleh Ria (2016) yang mengatakan bahwa inventory turnover dan receivable turnover secara simultan tidak memilki pengaruh terhadap ROA.

\section{Penutup}

\section{Kesimpulan}

Berdasarkan hasil pengujian secara bersama-sama diperoleh bahwa Perputaran Piutang dan Perputaran Persediaan berpengaruh signifikan terhadap ROA. Secara Parsial atau individu Perputaran Piutang tidak berpengaruh terhadap ROA sedangkan Perputaran Persediaan berpengaruh positif dan signifikan terhadapn ROA.

\section{Saran}

Berdasarkan penelitian yang telah dilakukan, penelitian ini jauh dari kata sempurna. Maka saran-saran yang dapat diberikan oleh penulis adalah bagi subsektor otomotif dan komponen diharapkan dapat mengelola piutangnya dengan mempercepat penagihan piutang sehingga perputaran piutang dapat meningkatkan ROA perusahaan. Selain itu, diharapkan 
perusahaan dapat mempertahankan perputaran persediaannya agar mampu mempertahankan eksistensi perusahaan. Bagi peneliti selanjutnya, sebaiknya dapat memperluas penentuan sampel atau dapat menambah variabel lain yang dapat mempengaruhi ROA.

\section{Daftar Pustaka}

Ananda, Febryandhie, and Ully Warma Dewi. 2019. "Pengaruh Perputaran Piutang, Perputaran Persediaan, Likuiditas, Solvabilitas Terhadap Profitabilitas Pada Pt. Semen Padang Periode 2007-2016." Academic confence of accounting.

Badan Pusat Statistik. 2020. "Pertumbuhan Ekonomi Indonesia Triwulan IV-2019." Www.Bps.Go.Id.

Basuki, Agus Tri dan, and Nano Prawoto. 2016. PT Rajagrafindo Persada Analisis Regresi Dalam Penelitian Ekonomi \& Bisnis: Dilengkapi Aplikasi SPSS \& EVIEWS.

CNBC Indonesia, Sektor Manufaktur RI 2019 Lesu, 11 Saham Otomotif Merana. https://cnbcindonesia.com/market/20200206164015-17-135908/sektor-manufaktur-ri2019-lesu-11-saham-otomotif-merana diakses pada Agustus 2019.

Deni, Irman. 2014. "Pengaruh Tingkat Perputaran Kas, Perputaran Piutsng Dan Perputaran Persediaan Terhadap Profitabilitas Pada Perusahaan Manufaktur Yang Terdaftar Di Bursa Efek Indonesia." Jurnal Akuntansi. Fakultas Ekonomi. Universitas Maritim Raja Ali Haji. Kepulauan Riau.

García-Teruel, Pedro Juan, and Pedro Martínez-Solano. 2007. "Effects of Working Capital Management on SME Profitability." International Journal of Managerial Finance.

Imam Ghazali. 2013. Aplikasi Multivariate dengan Program IBM SPSS 21. Semarang: Universitas Diponegoro

Kasmir. 2014. Raja Grafindo Persada Analisis Laporan Keuangan, Edisi Satu, Cetakan Ketujuh.

Kementerian Perindustrian Republik Indonesia 2017, Industri Otomotif Berkontribusi Besar Bagi Ekonomi Nasional. https://kemenperin.go.id/artikel/17466/Industri-OtomotifBerkontribusi-Besar-Bagi-EkonomiNasional diakses pada Juni 2019

Kementerian Perindustrian Republik Indonesia 2019, Industri Otomotif Dibidik Jadi Sektor Primadona Ekspor Nasional. https://kemenperin.go.id/artikel/20965/Industri-OtomotifDibidik-Jadi-Sektor-Primadona-Ekspor-Nasional diakses pada Juni 2020

Khabilah Umayta, Irmanda, Nur Diana, and Afifudin. 2019. "Pengaruh Cash Turnover, Receivable Turnover, Dan Inventory Turnover Terhadap Return On Asset Perusahaan Properti Yang Terdaftar Di Bei Periode 2015-2017.” E-Jra.

Kurniawati dan Meria Fitri. 2015. Pengarub Perputaran Piutag dan Perputaran Persediaan Terhadap Tingkat Profitabilitas Perusahaan Otomotif dan Komponen Yang Terdaftar di BEI. Padang: Universitas Negeri Bandung.

Migang, Satriawaty, and Antika Irawan. 2019. "Pengaruh Cash Turnover, Working Capitalturnover, Receivable Turnover, Dan Inventory Turnover Terhadap Return On Asset Pada Perusahaan Keramik Yang Terdaftar Di Bursa Efek Indonesia." Jurnal GeoEkonomi.

Munawir. 2010. Jakarta: Salemba Empat Analisa Laporan Kenangan Edisi 4.

Muslimah, K. N. N., \& Syarief, M. E. (2020). Pengaruh Manajemen Modal Kerja Terhadap Kinerja Keuangan Perusahaan Manufaktur di Indeks Saham Syariah. Journal of Applied Islamic Economics and Finance, 1(1), 54-70. 
Nurafika, Rika Ayu. 2018. "Pengaruh Perputaran Kas, Perputaran Piutang, Perputaran Persediaan Terhadap Profitabilitas Pada Perusahaan Semen." JURNAL AKUNTANSI DAN BISNIS : Jurnal Program Studi Akuntansi.

Prakarsa, R. A., \& Setiawan, S. (2018, October). Pengaruh Profitabilitas, Leverage, Dan Ukuran Perusahaan Terhadap Praktik Perataan Laba (Studi Pada Perusahaan Keuangan Sub Sektor Perbankan Yang Terdaftar Di Bursa Efek Indonesia Periode 2015-2017). In Prosiding Industrial Research Workshop and National Seminar (Vol. 9, pp. 719-727).

Ria Gustini. 2016. Pengarub Inventory Turnover dan Receivable Turnover terbadap Return On Asset (ROA) Pada PT Ace Hardware Indonesia Tbk. dan Entitas Anak. Pontianak: Perguruan Tinggi Widya Dharma

Santoso dan Putri Ayu. 2016. Pengarub Perputaran Kas, Piutang, Persediaan Terhadap Profitabilitas Pada Perusabaan Semen di BEI. Bandung: Universitas Islam Bandung.

Sugiyono. 2018. Metode Penelitian Kuantitatif, Kualitatif, dan R\&D. Cetakan Ke-26. Bandung: Penerbit Alfabeta.

Widarjono, Agus. 2018. Universitas Terbuka Ekonometrika.

Wijaya, Linda Vania, and Lauw Tjun Tjun. 2018. "Pengaruh Cash Turnover, Receivable Turnover, Dan Inventory Turnover Terhadap Return On Asset Perusahaan Sektor Makanan Dan Minuman Yang Terdaftar Di Bursa Efek Indonesia Periode 2013 Â€“ 2015.” Jurnal Akuntansi Maranatha. 